University of Nebraska - Lincoln DigitalCommons@University of Nebraska - Lincoln

USGS Staff -- Published Research

US Geological Survey

2010

\title{
Who provided maize to Chaco Canyon after the mid-12th-century drought?
}

Larry V.Benson

U.S. Geological Survey, great.basin666@gmail.com

Follow this and additional works at: http:/ / digitalcommons.unl.edu/usgsstaffpub

Benson, Larry V., "Who provided maize to Chaco Canyon after the mid-12th-century drought?" (2010). USGS Staff -- Published Research. 754.

http:// digitalcommons.unl.edu/usgsstaffpub/754

This Article is brought to you for free and open access by the US Geological Survey at DigitalCommons@University of Nebraska - Lincoln. It has been accepted for inclusion in USGS Staff -- Published Research by an authorized administrator of DigitalCommons@University of Nebraska - Lincoln. 


\title{
Who provided maize to Chaco Canyon after the mid-12th-century drought?
}

\author{
Larry V. Benson* \\ U.S. Geological Survey, 3215 Marine Street, Boulder, CO 80303, United States
}

\section{A R T I C L E I N F O}

\section{Article history:}

Received 8 September 2009

Received in revised form

19 October 2009

Accepted 20 October 2009

\section{Keywords:}

Archaeological maize

Strontium isotopes

Chaco Canyon

San Juan Basin

\begin{abstract}
A B S T R A C T
Between A.D. 1181 and 1200, in the early part of a climatically wet period, corn was imported to Chaco Canyon from a region outside the Chaco Halo (defined in this paper as the region between the base of the Chuska Mountains and Raton Wells). Strontium-isotope $\left({ }^{87} \mathrm{Sr} /{ }^{86} \mathrm{Sr}\right.$ ) analyses of 12 corn cobs dating to this period match ${ }^{87} \mathrm{Sr} /{ }^{86} \mathrm{Sr}$ ratios from five potential source areas, including: the Zuni region, the Mesa Verde-McElmo Dome area, the Totah, the Defiance Plateau, and Lobo Mesa. The latter two areas were eliminated from consideration as possible sources of corn in that they appear to have been unpopulated during the time period of interest. Therefore, it appears that the corn cobs were imported from the Zuni region, the Mesa Verde-McElmo Dome area, or the Totah area during a time when the climate was relatively wet and when a surplus of corn was produced in regions outside Chaco Canyon. Based on proximity to and cultural affiliation with Chaco Canyon, it is hypothesized that the corn probably was imported from the Totah.
\end{abstract}

Published by Elsevier Ltd.

\section{Introduction}

In a recent paper, Benson et al. (2009) presented calibrated ${ }^{14} \mathrm{C}$ (calendar) ages for 36 corn cobs (hereafter referred to as cobs) from Chaco Canyon archaeological contexts, including ages for seven Pueblo Bonito cobs dated by Cordell et al. (2008). Twenty-one of the cobs from three great houses (Pueblo Bonito, Kin Klizhin, and Chetro Ketl) and Gallo Cliff Dwelling yielded a pooled ${ }^{14} \mathrm{C}$ age of $870 \pm 5$ years (yr) and a mean calibrated age of A.D. $1176 \pm 12 \mathrm{yr}$. Fifteen of the 21 cobs came from Gallo Cliff Dwelling. In the present study, an additional 10 cobs from Gallo Cliff Dwelling were ${ }^{14} \mathrm{C}$ dated with nine of them yielding a pooled ${ }^{14} \mathrm{C}$ age of $857 \pm 7 \mathrm{yr}$ and a mean calibrated age of A.D. $1196 \pm 15 \mathrm{yr}$. Thirty cobs from both studies yield a pooled ${ }^{14} \mathrm{C}$ age of $865 \pm 4 \mathrm{yr}$ and a mean calibrated age of A.D. $1180 \pm 10 \mathrm{yr}$.

These cobs date to the beginning of a wet period that followed the mid-12th-century megadrought (Fig. 1). At about A.D. 1130, during the initial phase of the mid-12th-century megadrought, the Chacoan system appears to have collapsed (Judge, 1989; Lekson, 1991). At that time all great house construction in Chaco Canyon ceased (see, e.g., Time Line 3 on p. 34 of Vivian and Hilpert, 2002) and most of the great houses in the San Juan Basin were abandoned (see Fig. 2 in Benson et al., 2007). However, it should be noted that great houses are not necessarily good indicators of population density; e.g., Windes (2003) has suggested that that the resident population of the 800-room Pueblo Bonito never exceeded 100 individuals.

\footnotetext{
* Tel.: +13035413005

E-mail address: lbenson@usgs.gov
}

Some Chaco Canyon great houses were used as habitation sites after A.D. 1130; e.g., Pueblo Bonito indicates limited evidence for habitation and substantial evidence for the use of kivas, some of which are Mesa Verdean in style (Windes, 2003). In addition, ceramic dating indicates that small houses may have occupied in the lower reaches of Chaco Canyon during the early A.D. 1100s and that there also was occupation of small houses in the Chaco East Community in the late A.D. 1100s (Windes et al., 2000).

It is not apparent, whether the people occupying Chaco Canyon in the A.D. 1180s represented a residual population, whether they had migrated to the Canyon during the mid-12th-century megadrought or at the beginning of a late-12th-century wet period (Fig. 1) or whether they were composed of a combination of residual-Chacoan and immigrant groups.

A comparison of the tree-ring-cutting-date distribution for the southern Colorado Plateau with a normalized tree-ring-based precipitation record for the southeastern Colorado Plateau (Fig. 1) shows that, in general, spikes in construction activities occurred during wet periods and that little or no construction occurred during the mid-12th- and late-13th-century megadroughts. These data indicate that climate change impacted prehistoric Native American populations in the southeastern Colorado Plateau and it is possible that people from outside Chaco Canyon in the A.D. 1180s attempted to reoccupy the Canyon during the early stages of a very wet period.

The objective of this study is to determine the source area(s) of Chaco Canyon cobs which date to the late A.D. 1180s. Were the cobs grown within the Chaco Halo - an area herein defined as stretching from Raton Wells on the east to the base of the Chuska Mountains 


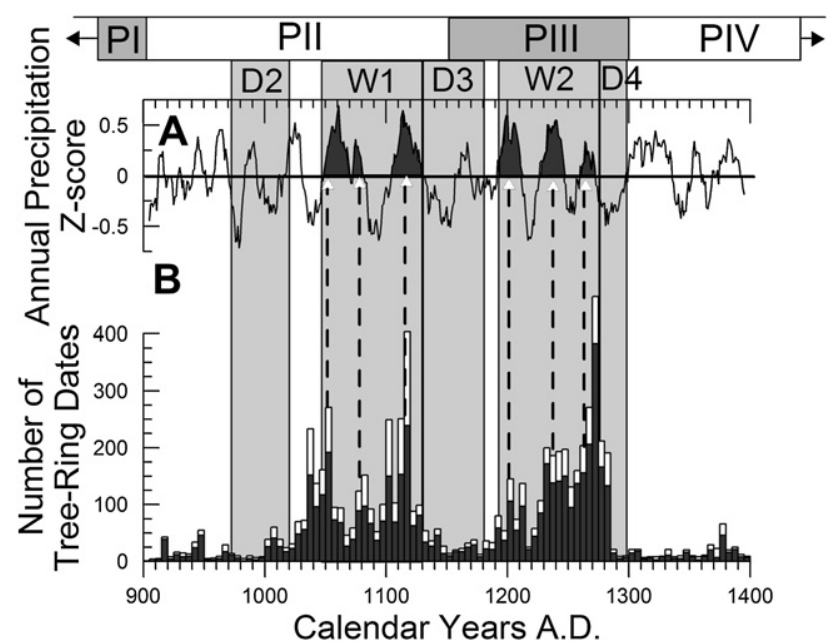

Fig. 1. Comparison of pan-regional tree cutting-date distribution with tree-ring-based precipitation records and archaeological stage boundaries. A. Mean of six normalized tree-ring-based precipitation records from sites within and at the edge of the San Juan Basin (data from Benson et al., 2007). For locations of climate records see Fig. 2 (black squares). B. Distribution of tree-ring dates for the period A.D. 900-1400 (data from Benson and Berry, 2009). Black values indicate "death" dates and white values indicate "v" dates (dates that are a few years older than the death date). Three megadroughts (D2-D4) have been colored light grey; two extended wet periods (W1-W2) have been colored dark grey. D3 is the mid-12th-century megadrought and D4 is the late-13thcentury megadrought. Dashed lines between cutting-date distribution and precipitation records between beginning of W1 and end of W2 indicate correlations of exceptionally wet times with intense tree harvesting and construction. P indicates Pueblo cultural stages.

on the west (Fig. 2$)^{1}$ - were they imported from an area within the southeastern Colorado Plateau to or from which Chacoans had previously migrated, or were they imported from one of the Great House communities that dominated the southeastern Colorado Plateau between A.D. 1050 and 1130? To answer these questions, ${ }^{87} \mathrm{Sr} /{ }^{86} \mathrm{Sr}$ ratios of cobs from the Chaco Canyon Gallo Cliff Dwelling structure and the Chetro Ketl great house, that date to the late A.D. 1180 s, were compared with ${ }^{87} \mathrm{Sr} /{ }^{86} \mathrm{Sr}$ ratios of synthetic soil waters from 174 sites within the southeastern Colorado Plateau area (Benson et al., 2009) and with synthetic soil waters from 30 sites within the Zuni Reservation.

\section{Chacoan connections}

If the archaeological cobs came from outside Chaco Canyon, it is reasonable to hypothesize they were imported from a community (or communities) that had a past or existing connection to people living in the Canyon. Lekson (2009:98) has suggested that people moving in to Mesa Verde during Pueblo I were descendants of those that built two large Chaco Canyon Basketmaker III sites (Shaik'eschee and site 29 SJ 423). Wilshusen and Van Dyke (2006) have suggested, using data gleaned from Chaco Canyon and the Navajo Reservoir area that emigrants from the Mesa Verde region moved into Chaco during the late-9th and 10th centuries. In an architectural sense, this concept is supported by the study of Wilshusen and Ortman (1999) who have shown that the area around the

\footnotetext{
${ }^{1}$ Doyel et al. (1984) first used the term "Chaco Halo" to indicate a high-density zone of occupation with a 5-km radius that surrounded Chaco Canyon and suggested that sites around the periphery of the Canyon acted to support the main Chaco megacommunity. This study assumes that the principal interaction ellipsoid (Halo) was composed of 12 great houses within the Canyon, the great houses and communities along the Rio Chaco east and west of the Canyon and the Chuska slope, the latter which has been shown to have supplied corn, timbers, chert, and pottery to the Canyon (Fig. 2) (Toll, 1991; English et al., 2001; Benson et al., 2003).
}

Dolores River, in southwest Colorado, was the site of horseshoeshaped roomblocks that may have acted as prototypes for early great houses in Chaco Canyon that began construction around A.D. 850.

Between A.D. 850 and A.D. 1130, twelve great houses were constructed in Chaco Canyon with accelerated construction occurring between A.D. 1050 and 1130. During the latter time interval, numerous other great houses were constructed within and outside the San Juan Basin (see Fig. 5.9 in Kantner and Kintigh, 2006). Cameron and Duff (2008) have succinctly summarized the debate regarding the relation of great house communities outside the Canyon and Chaco. On one side, Kantner and Kintigh (2006) argue that Chaco was an important religious center but it was not strongly connected politically or economically to great houses outside the Canyon. On the other side, Lekson (2006) believes that Chaco was a chiefdom that exercised ritual and political control of great house communities outside the Canyon. The author favors Lekson's (2006) concept of the Chaco world and accepts the arguments of Cameron and Duff (2008), which point to the fact that "Canyon leaders employed both cooperative and coercive strategies" with regard to communities external to the Canyon.

Even before the collapse of the Chacoan world at about A.D. 1130, there appears to have been a transfer in regional dominance from Chaco north to the Totah. Judge (1989: 247) was the first to suggest that "there was a shift in the administrative and ritual locus from Chaco to the San Juan area, perhaps to either Aztec or Salmon ...circa A.D. 1090-1100". Reed (2006) has argued that local San Juan residents were recruited by in-migrating Chacoans to be part of the original Salmon residential group and that the local indigenes remained in Salmon after A.D. 1125 (Reed, 2008). In addition, personal communication (2009) have argued that, during the McElmo phase, approximately A.D. 1140-1200, Aztec West was occupied by a mixed group of Chacoan and local people.

Kintigh et al. (2004) have suggested that some Chacoans migrated to the Zuni region during the early A.D. 1100s. In the valleys, surrounding the large prehistoric Zuni town of Heshatauthla, population expanded at an annual rate of $\sim 2 \%$ during the period A.D. 1125-1225 and then plateaued between A.D. 1225 and 1275 (Kintigh et al., 2004). While the rate of population increase in the Zuni region for the A.D. 1125-1225 period cannot be proven to have resulted from in-migration, megadrought characterized the southern Colorado Plateau between A.D. 1130 and 1177 (Fig. 1; see, e.g., Benson and Berry, 2009) and it is doubtful that populations expanded during this time period by means other than in-migration.

\section{Methods}

\subsection{Strontium isotopes}

A radiogenic isotope is one that was produced by the decay of a radionuclide, but which itself may or may not be radioactive. In the case of $\mathrm{Sr}$, there are two isotopes of interest, ${ }^{87} \mathrm{Sr}$ and ${ }^{86} \mathrm{Sr} .{ }^{86} \mathrm{Sr}$ is a stable isotope, whereas ${ }^{87} \mathrm{Sr}$ is a stable radiogenic isotope produced by the radioactive decay of ${ }^{87} \mathrm{Rb}$ with a half-life of 48.8 billion years. Thus the ${ }^{87} \mathrm{Sr} /{ }^{86} \mathrm{Sr}$ ratio of a rock and the soil derived from it is a function of the initial ${ }^{87} \mathrm{Sr} /{ }^{86} \mathrm{Sr}$ ratio of the rock, its age, and the amount of ${ }^{87} \mathrm{Rb}$ initially present in the rock. However, the rate of production of ${ }^{87} \mathrm{Sr}$ from ${ }^{87} \mathrm{Rb}$ is so slow that the ${ }^{87} \mathrm{Sr} /{ }^{86} \mathrm{Sr}$ ratio can be considered invariant over archaeological timescales.

The isotopes of $\mathrm{Sr}$ are nearly identical in their physical and chemical properties; therefore, isotopic fractionation does not occur during chemical and physical transformations. In terms of $\mathrm{Sr}$ delivery to a plant, the soil water takes on the ${ }^{87} \mathrm{Sr} /{ }^{86} \mathrm{Sr}$ ratio of the soil's soluble mineral components; e.g., calcium carbonate and clay mineral ion-exchange sites can release $\mathrm{Sr}$ to soil water. The $\mathrm{Sr}$ in the soil water is biologically available, and so the ${ }^{87} \mathrm{Sr} /{ }^{86} \mathrm{Sr}$ ratio is, in turn, transferred unchanged to the plant. 


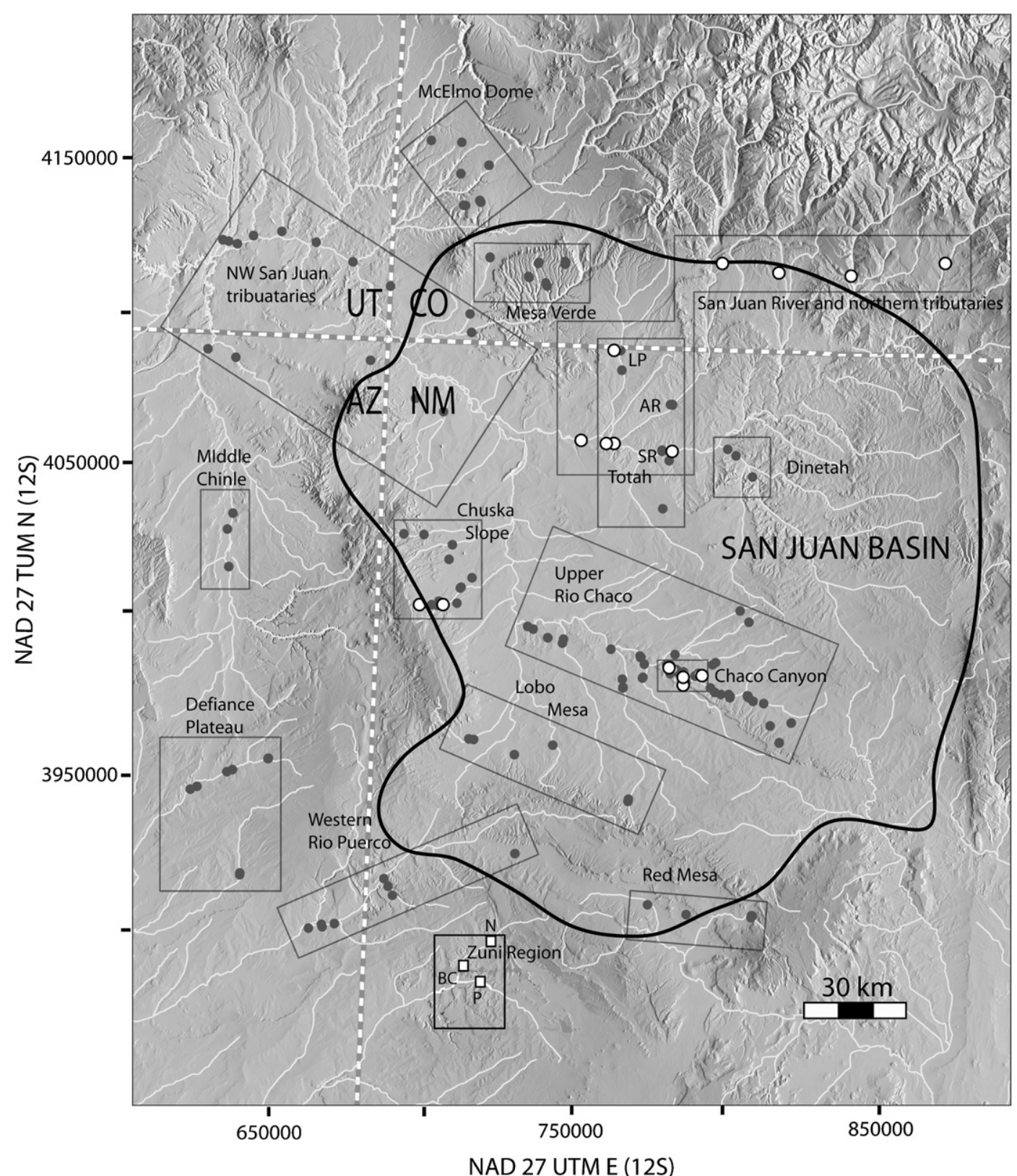

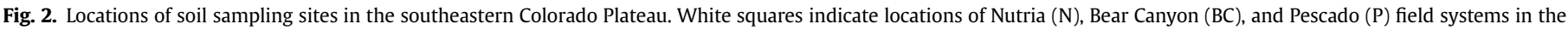

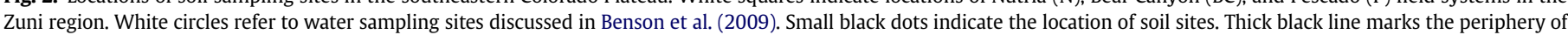

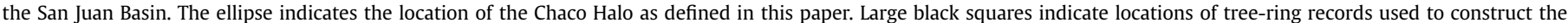
precipitation history shown in Fig. 1. North is at the top of the figure.

\subsection{Maize processing}

Chemical analyses of 22 cobs from Chaco Canyon (19 from Gallo Cliff Dwelling, two from Chetro Ketl, and one from Pueblo Bonito) are utilized in this study (Table 1 ). These analyses include ${ }^{14} \mathrm{C}$, trace metal, and ${ }^{87} \mathrm{Sr} /{ }^{86} \mathrm{Sr}$ data for 12 cobs previously studied by Benson et al. (2009).

An additional 10 cobs from Gallo Cliff Dwelling were processed in this study prior to trace metal and ${ }^{87} \mathrm{Sr} /{ }^{86} \mathrm{Sr}$ analyses, using the cleaning procedure successfully tested on burned cobs by Benson et al. (2010). The procedure consists of first treating pieces of crushed cob with hydrochloric $(\mathrm{HCl})$ acid to dissolve carbonate minerals. The cob pieces were then thoroughly rinsed to remove dissolved solids (especially $\mathrm{Ca}$, which could react and precipitate with $\mathrm{F}$ introduced in the subsequent procedure) and then treated with hydrofluoric (HF) acid to dissolve silicate minerals. The cob pieces were rinsed again and the sample ashed in a muffle furnace. After ashing, deionized (DI) water, nitric acid $\left(\mathrm{HNO}_{3}\right)$, and $\mathrm{HCl}$ were added to the sample and the solution was filtered to remove residual mineral particles.

Benson et al. (2010) have shown that unburned cobs tend to "leak" metals when exposed to a liquid for more than a few minutes. In this paper, the application of the cleaning procedure to the unburned Gallo Cliff Dwelling cobs was done in order to test whether sufficient $\mathrm{Sr}$, originally bound to weak ion-exchange sites in the cob, remained after cleaning. The cleaning procedure employed in this study differs from that used to treat the 12 cobs previously reported in Benson et al. (2010) (first set in Table 1 plus Chetro Ketl and Pueblo Bonito cobs); i.e., in the previous study, cleaning was confined to two physical processes: (1) the cupules 
Table 1

${ }^{87} \mathrm{Sr} /{ }^{86} \mathrm{Sr}$ ratios, ages, and $\mathrm{Al}$ and $\mathrm{Sr}$ concentrations of Gallo Cliff Dwelling and Chetro Ketl cobs.

\begin{tabular}{|c|c|c|c|c|c|c|c|c|c|c|c|}
\hline \multirow[t]{2}{*}{ Cob No. } & \multirow[t]{2}{*}{${ }^{87} \mathrm{Sr} /{ }^{86} \mathrm{Sr}$} & \multirow[t]{2}{*}{ Error (2 SD) } & \multicolumn{2}{|c|}{$\mathrm{Al}(\mu \mathrm{g} / \mathrm{g})$} & \multicolumn{2}{|c|}{$\mathrm{Sr}(\mu \mathrm{g} / \mathrm{g})$} & \multirow[t]{2}{*}{ UCIAMS No. } & \multirow{2}{*}{$\frac{{ }^{14} \mathrm{C} \text { age }}{(\mathrm{yr} \mathrm{BP})}$} & \multirow{2}{*}{$\frac{{ }^{14} \mathrm{C} \text { Error }}{(\mathrm{yr})}$} & \multirow[t]{2}{*}{ Cal. age range ( $1 \mathrm{SD}, \mathrm{yr})$} & \multirow[t]{2}{*}{ Cal. age midpt. (AD) } \\
\hline & & & Avg & SD & Avg & SD & & & & & \\
\hline \multicolumn{12}{|c|}{ Gallo Cliff Dwelling Cobs (First Set) } \\
\hline CHCU43684-1 & 0.710880 & 0.000014 & 243 & 10 & 3.4 & 0.0 & 23981 & 845 & 25 & $1170-1220$ & 1195 \\
\hline CHCU43684-3 & 0.709638 & 0.000011 & 106 & 2 & 4.7 & 0.1 & 23984 & 850 & 25 & $1170-1218$ & 1194 \\
\hline CHCU43684-5 & 0.709586 & 0.000015 & 50 & 2 & 4.1 & 0.0 & 23985 & 880 & 20 & $1156-1210$ & 1183 \\
\hline CHCU43684-6 & 0.709412 & 0.000011 & 133 & 1 & 8.0 & 0.1 & 23987 & 870 & 25 & $1160-1212$ & 1186 \\
\hline CHCU43684-8 & 0.709759 & 0.000011 & 101 & 4 & 3.5 & 0.0 & 23990 & 880 & 25 & $1155-1212$ & 1184 \\
\hline CHCU43684-9 & 0.710010 & 0.000014 & 171 & 7 & 3.1 & 0.0 & 23991 & 855 & 30 & $1162-1219$ & 1190 \\
\hline CHCU43684-10 & 0.709961 & 0.000014 & 102 & 2 & 4.5 & 0.1 & 23992 & 865 & 20 & 1167-1209 & 1188 \\
\hline CHCU43684-15 & 0.710143 & 0.000015 & 114 & 0 & 3.5 & 0.0 & 23998 & 875 & 20 & $1160-1208$ & 1184 \\
\hline CHCU43684-16 & 0.710094 & 0.000013 & 187 & 2 & 3.9 & 0.0 & 23999 & 885 & 20 & $1155-1208$ & 1182 \\
\hline $\operatorname{Avg} \pm \mathrm{SD}$ & 0.7099 & 0.0004 & 134 & 57 & 4.30 & 1.49 & \multirow{2}{*}{\multicolumn{3}{|c|}{ Pooled ${ }^{14} \mathrm{C}=869 \pm 8$}} & \multirow{2}{*}{\multicolumn{2}{|c|}{ Pooled calib $=1177 \pm 12$}} \\
\hline Range & $0.7094-0.7$ & 109 & & & & & & & & & \\
\hline \multicolumn{12}{|c|}{ Gallo Cliff Dwelling Cobs (Second Set) } \\
\hline CHCU43684A & 0.71155 & 0.00016 & 2.9 & 0.0 & 0.024 & 0.001 & 51908 & 900 & 20 & $1048-1085$ & 1066 \\
\hline CHCU43684B & 0.71000 & 0.00024 & 0.66 & 0.05 & 0.0077 & 0.0011 & 51896 & 855 & 20 & $1175-1214$ & 1194 \\
\hline CHCU43684C & 0.71103 & 0.00013 & 1.2 & 0.0 & 0.013 & 0.001 & 51897 & 860 & 20 & $1171-1211$ & 1191 \\
\hline CHCU43684D & 0.71335 & 0.00005 & 11 & 0 & 0.059 & 0.002 & 51898 & 865 & 20 & 1167-1209 & 1188 \\
\hline CHCU43684E & 0.71467 & 0.00005 & 4.8 & 0.0 & 0.022 & 0.001 & 51909 & 850 & 20 & $1176-1217$ & 1196 \\
\hline CHCU43684F & 0.71250 & 0.00027 & 1.5 & 0.0 & 0.012 & 0.001 & 51899 & 855 & 20 & $1175-1214$ & 1194 \\
\hline CHCU43684 G & 0.71089 & 0.00010 & 0.96 & 0.00 & 0.011 & 0.000 & 51900 & 840 & 20 & $1177-1222$ & 1200 \\
\hline CHCU43684H & 0.71005 & 0.00005 & 1.6 & 0.0 & 0.015 & 0.002 & 51901 & 855 & 20 & $1175-1214$ & 1194 \\
\hline CHCU43684I & 0.71302 & 0.00011 & 3.5 & 0.1 & 0.028 & 0.001 & 51902 & 870 & 20 & $1163-1208$ & 1186 \\
\hline CHCU43684 J & 0.71183 & 0.00003 & 3.6 & 0.1 & 0.031 & 0.002 & 51903 & 865 & 20 & 1167-1209 & 1188 \\
\hline $\operatorname{Avg} \pm S D$ & 0.7119 & 0.0016 & 3.1 & 2.9 & 0.02 & 0.02 & \multirow{2}{*}{\multicolumn{3}{|c|}{ Pooled ${ }^{14} \mathrm{C}=857 \pm 7$}} & \multirow{2}{*}{\multicolumn{2}{|c|}{ Pooled calib $=1196 \pm 15$}} \\
\hline Range & $0.7100-0.7$ & 147 & & & & & & & & & \\
\hline \multicolumn{12}{|c|}{ Chetro Ketl Cobs Room 92} \\
\hline CHCU32288-1 & 0.709523 & 0.000014 & 131 & 7 & 11 & 0 & 23975 & 880 & 20 & $1156-1210$ & 1183 \\
\hline CHCU32288-2 & 0.709350 & 0.000009 & 91 & 2 & 22 & 0 & 23976 & 870 & 20 & 1163-1208 & 1186 \\
\hline $\operatorname{Avg} \pm \mathrm{SD}$ & 0.7094 & 0.0001 & 111 & 29 & 16 & 8 & \multirow{2}{*}{\multicolumn{3}{|c|}{ Pooled ${ }^{14} \mathrm{C}=875 \pm 14$}} & \multirow{2}{*}{\multicolumn{2}{|c|}{ Pooled calib $=1170 \pm 10$}} \\
\hline Range & $0.7094-0.7$ & 095 & & & & & & & & & \\
\hline \multicolumn{12}{|c|}{ Pueblo Bonito Room 3} \\
\hline $\mathrm{H} 254 / 258 \mathrm{~A}$ & 0.709394 & 0.000010 & 160 & 10 & 18 & 1 & Beta-188112 & 890 & 40 & $1151-1211$ & 1181 \\
\hline
\end{tabular}

and outer part of the cob were removed with a titanium knife, and (2) visible contamination (sediment) also was removed. In that study, acids were not applied to the cobs to remove mineral particles; therefore, dissolution of some residual silicate particles (containing $\mathrm{Sr}$ ) with $\mathrm{HF}$ after ashing may have slightly biased the ${ }^{87} \mathrm{Sr} /{ }^{86} \mathrm{Sr}$ data obtained on the original 12 cobs.

\subsection{Radiocarbon dating of the archaeological cobs}

Radiocarbon $\left({ }^{14} \mathrm{C}\right)$ analyses of the 22 cobs (Table 1 ) examined in this study were performed at the Keck Carbon Cycle Accelerator Mass Spectrometer (AMS) Facility at the University of California, Irvine campus, under the supervision of John Southon. The ${ }^{14} \mathrm{C}$ ages of the cobs were calibrated (converted to calendar years) using CALIB 5.0.1 (Stuiver et al., 2005). Radiocarbon ages of cobs that dated to the A.D. 1180 s and early 1190 s were pooled in order to determine mean calibrated ages for various cob sets (Table 1 ).

\subsection{Soil collection and processing}

This study combines previously published ${ }^{87} \mathrm{Sr} /{ }^{86} \mathrm{Sr}$ analyses of soils from approximately 174 sites within the southeastern Colorado Plateau area with new ${ }^{87} \mathrm{Sr} /{ }^{86} \mathrm{Sr}$ analyses of soils from 30 sites within the Zuni Reservation (Figs. 2, 3).

At Zuni, 10 sites in each of three field areas (Bear Canyon, Nutria, and Pescado) were sampled by hand auger. These sites were some of those previously sampled by Homburg et al. (2005) in a study of the relative productivity of cultivated and uncultivated fields in the Zuni region. At each of 30 locations (Fig. 3) (Supplementary Table 1), four samples, each $225 \mathrm{~cm}^{3}$ in volume, were collected at depths of 10-16, $40-46,70-76$, and $100-106 \mathrm{~cm}$. In order to produce a synthetic soil water ${ }^{2}$ containing bioavailable $\mathrm{Sr}$, soils were air dried, homogenized, and a 5-g subsample of soil combined from the four depth intervals was leached for $48 \mathrm{~h}$ with constant agitation, using $500 \mathrm{~mL}$ of $1-\mathrm{M}$ acetic acid prepared from distillation-purified glacial-acetic acid. These samples were sequentially filtered through $0.4-$ and $0.2-\mu \mathrm{m}$ pore-size membrane filters prior to analysis.

\subsection{Comparison of synthetic soil water ${ }^{87} \mathrm{Sr} /{ }^{86} \mathrm{Sr}$ values with} ${ }^{87} \mathrm{Sr} /{ }^{86} \mathrm{Sr}$ values of cobs grown from those soils

In this study we also retested the hypothesis that the dissolution of soils with a weak acid produced ${ }^{87} \mathrm{Sr} /{ }^{86} \mathrm{Sr}$ ratios that are nearly identical to the biologically available ${ }^{87} \mathrm{Sr} /{ }^{86} \mathrm{Sr}$ ratios fixed by the maize plant. The ${ }^{87} \mathrm{Sr} /{ }^{86} \mathrm{Sr}$ ratios of four Southwestern Native American cobs grown out at Farmington, New Mexico, in a project headed by D. Muenchrath, Iowa State (Adams et al., 2006), were obtained on clean samples that were freeze dried and ashed. These data were compared with the ${ }^{87} \mathrm{Sr} /{ }^{86} \mathrm{Sr}$ ratios of synthetic soils waters produced by reacting soil samples composited from each

\footnotetext{
2 Synthetic soil waters are produced by leaching a soil sample with a weak acid in order to reproduce a soil-water composition that contains biologically available metals. See Methods section for details of this procedure.
} 


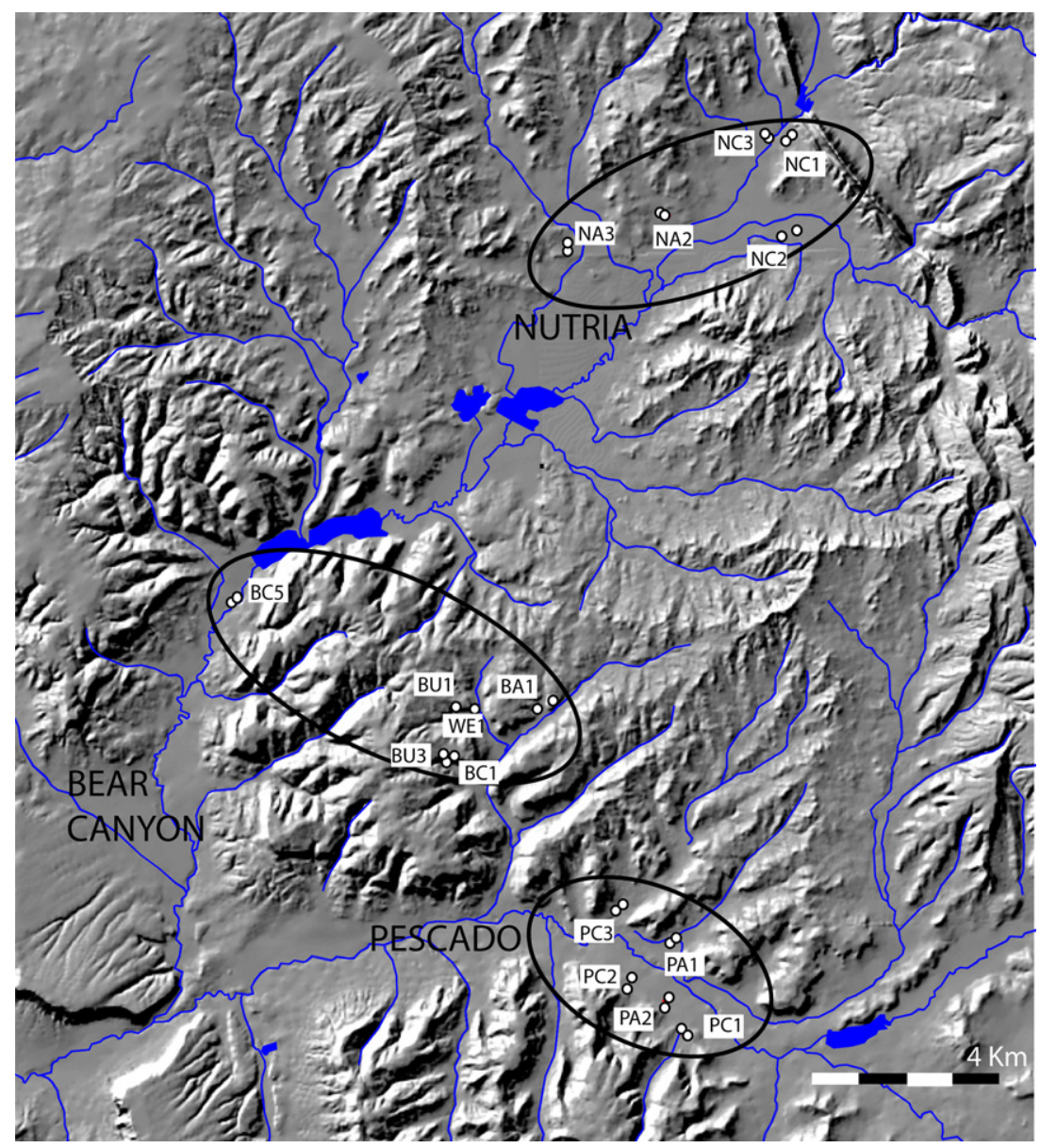

Fig. 3. Locations of soil sampling sites in the Zuni region of New Mexico. North is at the top of the figure. Zuni region location relative to study area is shown in Fig. 2 .

root zone with purified acetic acid (Section 3.3) (Table 2). Traceelement data for the Farmington cobs and their synthetic soil waters can be found in Benson et al. (2008).

\subsection{Trace-metal analysis of cob digests and soil leaches}

Multi-element trace-metal determinations were performed using inductively coupled plasma-mass spectrometry (ICP-MS) and inductively coupled plasma-atomic emission spectrometry (ICPAES) (Garbarino and Taylor, 1993; Boss and Fredeen, 1999; Taylor, 2001). All measurements were made on aqueous sample solutions without preconcentration, using direct pneumatic nebulization with a Perkin-Elmer Elan 6000 instrument (ICP-MS) or a PerkinElmer Optima 3300 DV (ICP-AES $)^{3}$. Trace metals in the cobs are listed in Supplementary Table 2.

\subsection{Strontium-isotope analysis of cob digests and soil leaches}

Strontium chemical separations and isotopic determinations were conducted in a Class 1-10,000 clean room at the University of Colorado, Boulder, Colorado by Emily Verplanck. Strontium separates were obtained using a Sr-specific resin ( $\mathrm{Sr}$ resin SPS, Eichrom Technologies, Inc.). The value of the total procedural blank for $\mathrm{Sr}$ was $\sim 30 \mathrm{pg}$. Strontium isotopic measurements were obtained

\footnotetext{
${ }^{3}$ Use of trade names is for descriptive purposes only and does not imply endorsement by the U.S Geological Survey.
}

using a Finnigan-MAT 261 thermal-ionization mass spectrometer in 4-collector static mode.

\section{Results}

4.1. Comparison of ${ }^{87} \mathrm{Sr} /{ }^{86} \mathrm{Sr}$ ratios in Farmington synthetic soil waters and cobs

The data listed in Table 2 indicate that Farmington cobs have slightly higher values (0-4 units in the fourth decimal place) than in synthetic waters produced from the soils in which the cobs grew. This suggests that the weak acid used to release metals from soluble mineral phases in the soils leaches a minor amount of $\mathrm{Sr}$ from mineral sources that are normally not biologically available.

\section{2. ${ }^{14} \mathrm{C}$ ages of the new set of Gallo Cliff Dwelling cobs}

Nine of the 10 cobs in the new (second) set from Gallo Cliff Dwelling have nearly identical ${ }^{14} \mathrm{C}$ ages with a mean calibrated age of A.D. $1196 \pm 15 \mathrm{yr}$ (Table 1), which is nearly the same as the mean calibrated age of 21 cobs (A.D. $1180 \pm 9 \mathrm{yr}$ ) previously dated by Benson et al. (2009). This indicates that most of the Gallo Cliff Dwelling, Chetro Ketl, Pueblo Bonito, and Kin Kletso cobs, dating individually to the A.D. 1180s and early 1190s, were probably brought into Chaco Canyon at about the same time and may have come from a single source area.

The cobs date to the beginning of a 25 -yr wet interval that began in A.D. 1185 and which followed the mid-12th-century 
Table 2

$\mathrm{Al}, \mathrm{La}, \mathrm{Sr}$, and ${ }^{87} \mathrm{Sr} /{ }^{86} \mathrm{Sr}$ values of Farmington cobs and soils.

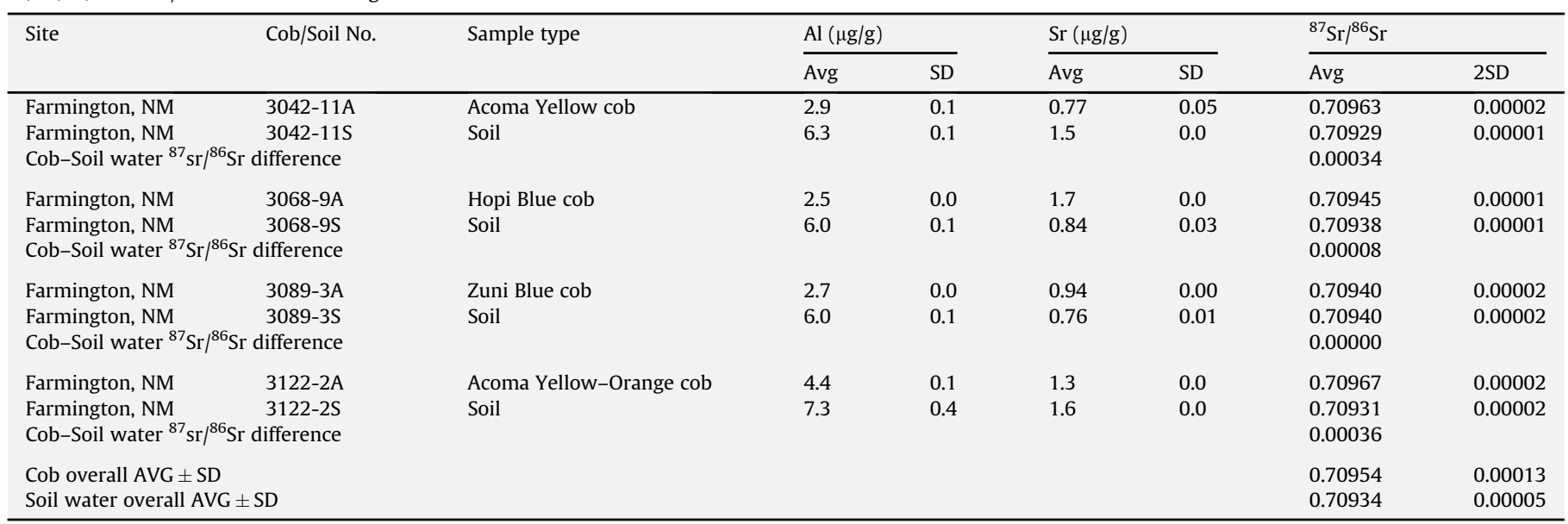

megadrought (Fig. 1). This may indicate that the corn was imported during a time in which people outside Chaco had a sufficient surplus that could be shared with kin groups that had remained in the Canyon during the drought or that corn was being successfully grown within the Canyon.

The anomalous A.D. 1066 date obtained on Gallo Cliff Dwelling cob CHCU43684A (Table 1) is similar to an A.D. 1070 date previously obtained on another Gallo Cliff Dwelling cob CHCU43684-4 dated by Benson et al. (2009). Gallo Cliff Dwelling itself appears to date to the late A.D. 1100s based on ceramic and other data sets (Tom Windes, personal communication, 2009); thus, the two older cobs may have been taken from an older structure in Chaco and placed in Gallo Cliff Dwelling at a later time.

\subsection{Sr contamination of cobs: insights from trace-element and} ${ }^{87} \mathrm{Sr} /{ }^{86} \mathrm{Sr}$ data sets

Archaeological cobs are often contaminated with mineral dust. This dust will usually contain aluminosilicate mineral particles (e.g., feldspar-KAlSi ${ }_{3} \mathrm{O}_{8}-\mathrm{NaAlSi}_{3} \mathrm{O}_{8}-\mathrm{CaAl}_{2} \mathrm{Si}_{2} \mathrm{O}_{8}$ ). Sr can substitute for $\mathrm{K}$, $\mathrm{Na}$, or $\mathrm{Ca}$ in the aluminosilicate minerals; therefore, the ${ }^{87} \mathrm{Sr} /{ }^{86} \mathrm{Sr}$ ratio of the mineral $\mathrm{Sr}$ can mask the ${ }^{87} \mathrm{Sr} /{ }^{86} \mathrm{Sr}$ ratio of the cob $\mathrm{Sr}$ in the mineral contaminant ${ }^{87} \mathrm{Sr} /{ }^{86} \mathrm{Sr}$ ratio differs greatly from the ${ }^{87} \mathrm{Sr} /{ }^{86} \mathrm{Sr}$ ratio of the cob. One way to determine if the ${ }^{87} \mathrm{Sr} /{ }^{86} \mathrm{Sr}$ ratio of an archaeological cob is being overwhelmed by mineral $\mathrm{Sr}$ is to plot $\mathrm{Sr}$ versus $\mathrm{Al}$ for several cobs from the same location or cache. If $\mathrm{Sr}$ is correlated with $\mathrm{Al}$, it suggests that most of the $\mathrm{Sr}$ is due to mineral contamination and, therefore, the measured ${ }^{87} \mathrm{Sr} /{ }^{86} \mathrm{Sr}$ ratio is not representative of the cob ${ }^{87} \mathrm{Sr} /{ }^{86} \mathrm{Sr}$ ratio.

Chemical data (50 metals) for 19 Gallo Cliff Dwelling and two Chetro Ketl cobs are listed in Supplementary Table 2. Strontiumisotope ratios, $\mathrm{Al}$, and $\mathrm{Sr}$ values of the cobs are listed in Table 1. It is apparent from the data in Table 1 that the 10 cleaned cobs (referred to as the second set in Table 1 ) have $\mathrm{Al}$ and $\mathrm{Sr}$ values that are approximately two orders of magnitude less than the $\mathrm{Al}$ and $\mathrm{Sr}$ values of the cobs that were analyzed previously by Benson et al. (2009) (referred to as the first set in Table 1). The ${ }^{87} \mathrm{Sr} /{ }^{86} \mathrm{Sr}$ ratios of 7 of 10 cobs in the second set are also substantially higher than the ${ }^{87} \mathrm{Sr} /{ }^{86} \mathrm{Sr}$ ratios of cobs in the first set.

Comparisons between $\mathrm{Sr}$ versus $\mathrm{Al}$ and ${ }^{87} \mathrm{Sr} /{ }^{86} \mathrm{Sr}$ versus $\mathrm{Al}$ for both cobs sets with $\mathrm{Sr}$ versus $\mathrm{Al}$ and ${ }^{87} \mathrm{Sr} /{ }^{86} \mathrm{Sr}$ versus $\mathrm{Al}$ for cobs and synthetic soil waters from the Farmington study (Benson et al., 2008) (Fig. 4) indicate the following:

1. The $\mathrm{Al}$ and $\mathrm{Sr}$ values for the first set of Gallo Cliff Dwelling/ Chetro Ketl cobs are uncorrelated (Fig. 4A); however $\mathrm{Sr}$ is highly correlated with $\mathrm{Al}\left(R^{2}=0.74\right.$ when the outlier is excluded and $R^{2}=0.93$ when the outlier is included) in the second set of Gallo Cliff Dwelling cobs (Fig. 4B). Sr is also uncorrelated with $\mathrm{Al}$ in clean Zuni Blue cobs from the Farmington study (Fig. 4D).

2. Sr and $\mathrm{Al}$ in synthetic soil waters created from root-zone soils of Acoma Yellow and Zuni Blue corn produced in the Farmington study are highly correlated (Fig. 4C) $\left(R^{2}=0.69\right.$ and 0.72$)$. These

Table 3

Zuni synthetic soil-water ${ }^{87} \mathrm{Sr} /{ }^{86} \mathrm{Sr}$ values.

\begin{tabular}{|c|c|c|c|c|c|c|c|c|}
\hline \multirow{2}{*}{$\begin{array}{l}\text { Site No. } \\
\text { Bear Canyon fields }\end{array}$} & \multirow[t]{2}{*}{${ }^{87} \mathrm{Sr} /{ }^{86} \mathrm{Sr}$} & \multirow[t]{2}{*}{ Error $(2 \sigma)$} & Site No. & \multirow[t]{2}{*}{${ }^{87} \mathrm{Sr} /{ }^{86} \mathrm{Sr}$} & \multirow[t]{2}{*}{ Error $(2 \sigma)$} & \multirow{2}{*}{$\begin{array}{l}\text { Site No. } \\
\text { Pescado }\end{array}$} & \multirow[t]{2}{*}{${ }^{87} \mathrm{Sr} /{ }^{86} \mathrm{Sr}$} & \multirow[t]{2}{*}{ Error $(2 \sigma)$} \\
\hline & & & Nutria fields & & & & & \\
\hline BA1A & 0.710172 & 0.000013 & NA2A & 0.70962 & 0.000016 & PA1A & 0.710303 & 0.000014 \\
\hline BA1B & 0.710606 & 0.000013 & NA2B & 0.70955 & 0.000016 & PA1B & 0.710090 & 0.000011 \\
\hline $\mathrm{BC} 1 \mathrm{~A}$ & 0.710878 & 0.000016 & NA3A & 0.71027 & 0.000015 & PA2A & 0.710997 & 0.000015 \\
\hline BC1B & 0.711364 & 0.000011 & NA3B & 0.71022 & 0.000012 & PA2B & 0.710707 & 0.000010 \\
\hline BC5A & 0.710443 & 0.000008 & NC1A & 0.70944 & 0.000015 & PC1A & 0.711229 & 0.000015 \\
\hline BC5B & 0.710426 & 0.000016 & NC1B & 0.71102 & 0.000015 & PC1B & 0.711122 & 0.000013 \\
\hline BU1 & 0.711121 & 0.000015 & $\mathrm{NC} 2 \mathrm{~A}$ & 0.70978 & 0.000010 & $\mathrm{PC} 2 \mathrm{~A}$ & 0.710932 & 0.000010 \\
\hline BU3A & 0.711083 & 0.000016 & $\mathrm{NC2B}$ & 0.70959 & 0.000014 & PC2B & 0.711349 & 0.000009 \\
\hline BU3B & 0.710873 & 0.000015 & $\mathrm{NC} 3 \mathrm{~A}$ & 0.71075 & 0.000011 & PC $3 \mathrm{~A}$ & 0.710209 & 0.000014 \\
\hline WE1 & 0.711199 & 0.000015 & $\mathrm{NC3B}$ & 0.71058 & 0.000008 & РС $3 \mathrm{~B}$ & 0.710264 & 0.000014 \\
\hline $\operatorname{Avg} \pm 1 \sigma$ & 0.7108 & 0.0004 & & 0.7101 & 0.0006 & & 0.7107 & 0.0005 \\
\hline Range & \multicolumn{2}{|c|}{$0.7102-0.7114$} & & \multicolumn{2}{|c|}{$0.7094-0.7110$} & & \multicolumn{2}{|c|}{$0.7101-0.7113$} \\
\hline Overall range & \multicolumn{2}{|c|}{$0.7094-0.7114$} & & & & & & \\
\hline
\end{tabular}


A
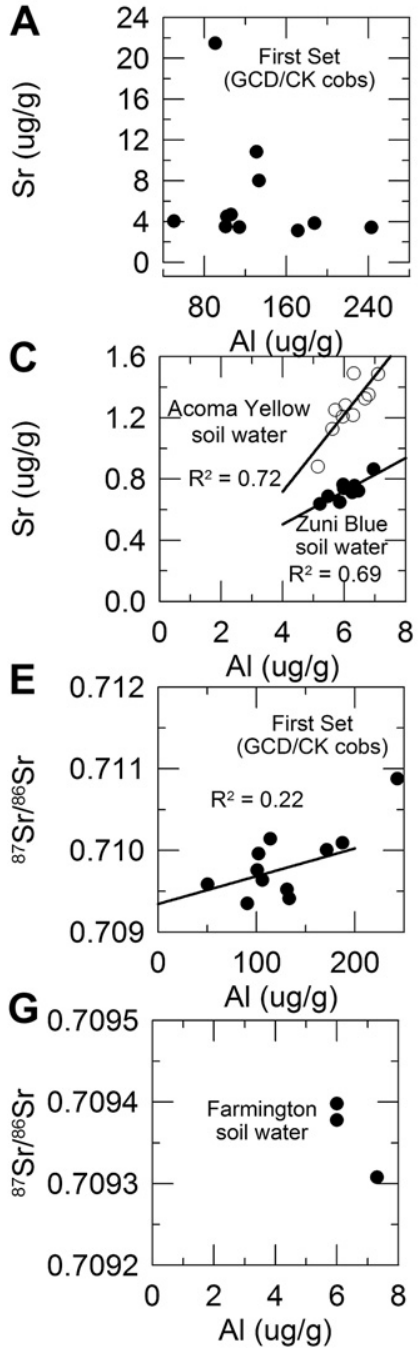

$80 \quad 160 \quad 240$

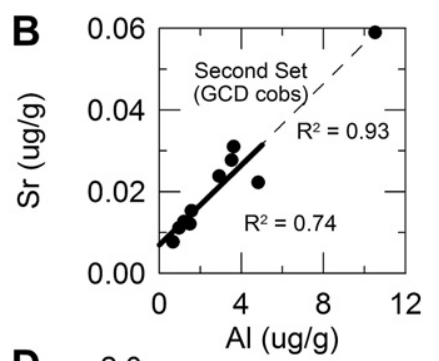

D

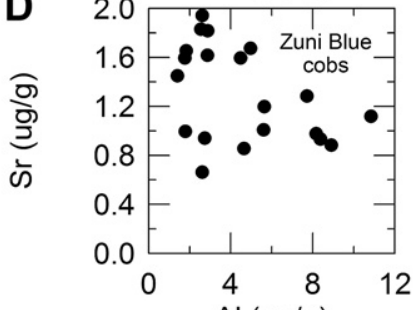

F

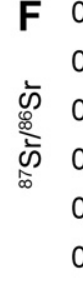

12

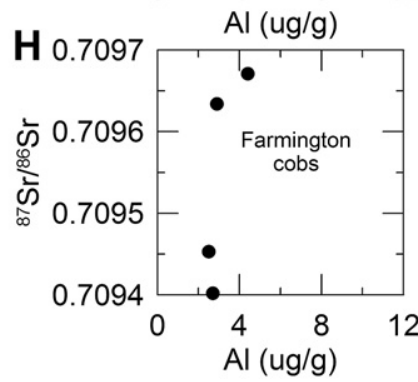

Fig. 4. Strontium isotope, $\mathrm{Sr}$, and $\mathrm{Al}$ values for cobs and synthetic soil waters discussed in this study. $\mathrm{GCD}=$ Gallo Cliff Dwelling; $\mathrm{CK}=$ Chetro Ketl, First Set refers to cobs published in Benson et al. (2009); Second Set refers to cobs analyzed in this paper.

$R^{2}$ values are similar to the $R^{2}$ value $(0.74)$ of the unlevered correlation of $\mathrm{Sr}$ and $\mathrm{Al}$ in the second cob set (Fig. 4B).

3. ${ }^{87} \mathrm{Sr} /{ }^{86} \mathrm{Sr}$ and $\mathrm{Al}$ are weakly correlated $\left(R^{2}=0.22\right)$ in the first set of Gallo Cliff Dwelling/Chetro Ketl cobs; but are relatively well correlated $\left(R^{2}=0.45\right)$ in the second set of Gallo Cliff Dwelling cobs (Fig. 4E, F).

4. No correlation exists between ${ }^{87} \mathrm{Sr} /{ }^{86} \mathrm{Sr}$ and $\mathrm{Al}$ in synthetic Farmington soil waters and cobs grown from those soils (Fig. 4G, H).

The fact that $\mathrm{Sr}$ and $\mathrm{Al}$ in the second Gallo Cliff Dwelling cob set are highly correlated and that $\mathrm{Sr}$ and $\mathrm{Al}$ in the modern Zuni Blue cobs are uncorrelated (compare Fig. 4B with Fig. 4D) indicates that $\mathrm{Sr}$ and $\mathrm{Al}$ in the second cob set do not, for the most part, derive from the organic matter that comprised the cob. Instead, the fact that $\mathrm{Sr}$ and $\mathrm{Al}$ in synthetic soil waters from the Farmington study also are well correlated (Fig. 4C) suggests that the $\mathrm{Sr}$ and $\mathrm{Al}$ in the second cob set derive from residual mineral contamination, either a single mineral (or mineral colloid) or a homogeneous mixture of minerals with a fixed $\mathrm{Sr} / \mathrm{Al}$ ratio. This suggestion is supported by the fact that the ${ }^{87} \mathrm{Sr} /{ }^{86} \mathrm{Sr}$ ratio of the second set of cobs increases with increasing $\mathrm{Al}$ (Fig. 4F); i.e., increasing mineral content of the sample. This relationship does not hold in the four Farmington cobs that were analyzed for ${ }^{87} \mathrm{Sr} /{ }^{86} \mathrm{Sr}$ in this study (Fig. $4 \mathrm{H}$ ). Therefore, it appears that the cleaning process has stripped the second set of cobs of their organically bound metals and that a small amount of Sr-containing mineral matter or mineral-rich colloidal material escaped the filtration step that preceded chemical analysis. In addition, the relatively elevated ${ }^{87} \mathrm{Sr} /{ }^{86} \mathrm{Sr}$ ratios $(>0.7109)$ of $70 \%$ of the second set of cobs (Table 1) are consistent with values of the most mineral-contaminated cobs previously analyzed by Benson et al. (2009). Thus, the ${ }^{87} \mathrm{Sr} /{ }^{86} \mathrm{Sr}$ ratios of the second set of cobs mostly result from mineral/colloid contamination and cannot be used to determine where the corn was grown.

A question arises as to why the burned cobs processed in the same manner by Benson et al. (2009) were able to retain sufficient organically bound $\mathrm{Sr}$ for ${ }^{87} \mathrm{Sr} /{ }^{86} \mathrm{Sr}$ analysis. According to B.R.T. Simoneit at Oregon State University (personal communication, 2009), corn is full of starch, cellulose and sugars, which all char upon roasting/grilling to activated carbon with charcoal. These materials are coated with lignin and lipid breakdown products. The activated carbon together with the fatty acid and methoxyphenol breakdown products are excellent scavengers for trace metals and the metal-organic bond strengths which characterize burned cobs are much stronger than the weak ionexchange sites that characterize unburned cobs.

\subsection{Comparison of ${ }^{87} \mathrm{Sr} /{ }^{86} \mathrm{Sr}$ values in the first set of Gallo Cliff} Dwelling, Chetro Ketl, and Pueblo Bonito cobs with ${ }^{87} \mathrm{Sr} /{ }^{86} \mathrm{Sr}$ values of synthetic soil waters from the southern Colorado Plateau

The locations of soil samples collected from the southern Colorado Plateau are shown in Fig. 2 and Zuni region soil sample locations also are shown in Figs. 2 and 3. In Fig. $5,{ }^{87} \mathrm{Sr} /{ }^{86} \mathrm{Sr}$ boxand-whisker plots for 12 Gallo Cliff Dwelling, Chetro Ketl, and Pueblo Bonito cobs (GC/CK/PB) are compared with ${ }^{87} \mathrm{Sr} /{ }^{86} \mathrm{Sr}$ boxand-whisker plots for synthetic soil waters from each of 14 sample regions (data from Benson et al., 2009). The soil sample locations are enclosed by rectangles in Fig. 2 and include the three Zuni field systems shown in Fig. 3. In Fig. 5, the first and third quartiles are at the lower and upper ends of the box, the median (second quartile) is indicated with a horizontal line in the interior of the box, and the maximum and minimum are represented by bars at the ends of the whiskers. The black dots in the Mesa Verde-McElmo Dome boxand-whisker plot represent outliers in the data sets.

It would be reasonable to expect that some of the cobs had been grown in the Canyon, especially along Gallo Wash which borders Gallo Cliff Dwelling; however, the Gallo Wash synthetic soil-water ${ }^{87} \mathrm{Sr} /{ }^{86} \mathrm{Sr}$ ratios range from 0.7090 to 0.7093 (Supplementary Table 1 in Benson et al., 2009) whereas the Gallo Cliff Dwelling cob ${ }^{87} \mathrm{Sr} /{ }^{86} \mathrm{Sr}$ ratios range from 0.7094 to 0.7109 (Table 1 ). In addition, none of the ${ }^{87} \mathrm{Sr} /{ }^{86} \mathrm{Sr}$ box-and-whisker plots for soils within the Chaco Canyon Halo (which includes samples from the Chuska Slope (CS)), the Rio Chaco floodplain (CFP) within the Canyon, side-valley alluvial fans within the Canyon (CSV), and floodplain and side-valley tributaries along the upper Rio Chaco both east and west of the Canyon (URC) are a good match for the A.D. $1180 \mathrm{~s} \mathrm{cob}{ }^{87} \mathrm{Sr} /{ }^{86} \mathrm{Sr}$ box-and-whisker plot data. These data rule out the Chaco Halo as a source of the cobs.

On the other hand, the ${ }^{87} \mathrm{Sr} /{ }^{86} \mathrm{Sr}$ data (Fig. 5) indicate that the Nutria field area in the Zuni (ZN) region, the Mesa Verde-McElmo Dome (MVMD) area, the Totah (TO) area, the Defiance Plateau (DP), and Lobo Mesa (LM) are candidate source areas for the cobs that date to the A.D. 1180s.

Some of the possible cob source areas apparently were not inhabited during the A.D. 1180s. The Lobo Mesa sites of Kin Ya'a, Peach Spring, and Red Willow are Chacoan in age; i.e., they were occupied from approximately A.D. 1000 to 1150 and the Corn Field Ruin, Kin Lichee, Kin Tiel, and Wide Reed Ruin sites in the Defiance Plateau were occupied after the A.D. 1180s; i.e., approximately A.D. 


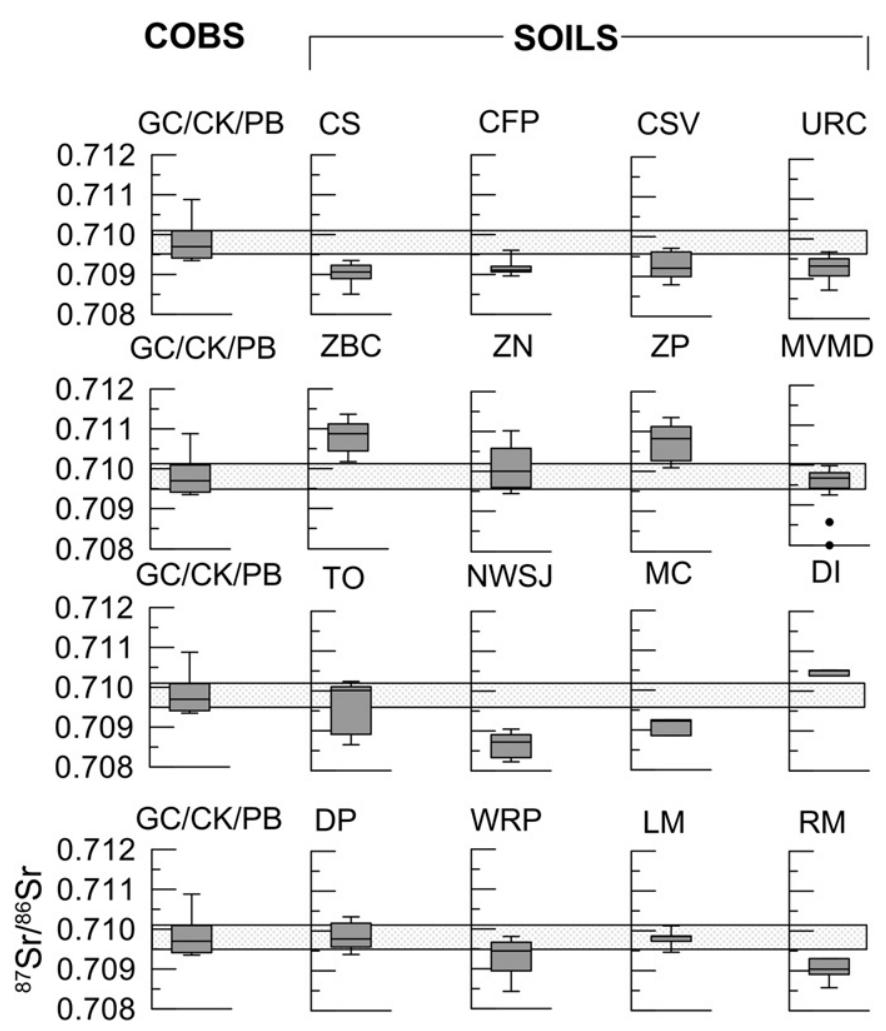

Fig. 5. ${ }^{87} \mathrm{Sr} /{ }^{86} \mathrm{Sr}$ box-and-whisker diagrams for clean cobs that date to the A.D. $1180 \mathrm{~s}$ compared with ${ }^{87} \mathrm{Sr} /{ }^{86} \mathrm{Sr}$ box-and-whisker diagrams for 14 soils areas depicted in Fig. 2. $\mathrm{CS}=$ Chuska Slope, $\mathrm{CFP}=$ Chaco Canyon floodplain, $\mathrm{CSV}=$ Chaco Canyon sidevalley tributaries (alluvial fans), URC $=$ Upper Rio Chaco; $\mathrm{ZBC}=\mathrm{Zuni}$ Bear Canyon, $\mathrm{ZN}=$ Zuni Nutria, ZP = Zuni Pescado, MVMD = Mesa Verde-McElmo Dome (northeastern San Juan Basin); TO =Totah, NWSJ = Northwestern San Juan Basin, $\mathrm{MC}=$ Middle Chinle, $\mathrm{Di}=$ Dinetah; $\mathrm{DP}=$ Defiance Plateau, $\mathrm{WRP}=$ Western Rio Puerco, $\mathrm{LM}=$ Lobo Mesa, $\mathrm{Rm}=$ Red Mesa Zuni Sr-isotope measurments are listed in (Table 3).

1250-1300 (Fowler and Stein, 1992). Tree-ring cutting dates from Wide Reed Ruin indicate that construction occurred there between A.D 1220 and 1300 (data from Benson and Berry, 2009). In the area around Wide Reed Ruin, construction occurred between A.D. 800 and 1030, A.D. 1070 and 1140, and between A.D. 1220 and 1290. These data confine possible source areas for Gallo Cliff Dwelling and Chetro Ketl cobs to the Zuni region, Mesa Verde-McElmo Dome, and Totah areas.

Chronometric data for the three potential source areas indicate that they were occupied in the A.D. 1180s. For example, population was on the rise in the Mesa Verde-McElmo dome area between A.D. 1050 and 1225 (Varien, 2002; Varien et al., 2007). In the Totah area, both Salmon Ruin and Aztec West were established on or before A.D. 1100 and populations persisted in this area until about A.D 1300 (Brown et al., 2008; Reed, 2008). The Zuni region was populated well before A.D. 1100 and remained so until at least A.D. 1275 when Heshatauthla was built (Kintigh et al., 2004). Thus, we are left with three areas which could have supplied corn to Chaco Canyon in the A.D. 1180s - the Zuni region, the northeastern San Juan Basin (Mesa Verde-McElmo Dome), and the middle San Juan Basin (the Totah).

\subsection{Choosing between the three potential source areas}

It is difficult to objectively choose between the three potential source areas; however, the Totah area is nearest to Chaco Canyon (Fig. 2) and appears to be the area to which many Chacoans migrated in the early 12 th century.

It is not clear whether people residing in Chaco during and shortly after the mid-12th-century drought were indigenous or had in-migrated. McElmo-style structures, such as Kin Kletso, built shortly after A.D. 1125 (Lekson, 1986), were originally attributed to the movement of people from the northern San Juan region to Chaco (Vivian and Matthews, 1965); however, Lekson (1986) has argued that the building traits that Vivian and Matthews (1965) considered uniquely McElmo in style also were associated with Chaco Canyon great houses that had been constructed long before the early A.D. 1100s.

To further complicate the issue, McElmo Black-on-white ceramics, which originated in the Mesa Verde area, were introduced to Chaco Canyon and the middle San Juan Basin during the mid-12th-century drought and appear to have persisted in the Canyon until at least the late A.D. 1100s (Windes, et al., 2000). Whether introduction of this pottery involved the actual movement of people from the northern San Juan region to Chaco or whether the ceramic design was simply adopted by a residual Chacoan population remains unresolved.

If people moved from the northern San Juan region to Chaco, in an effort to reoccupy the Canyon in the late A.D. 1100s, one might expect that they would have received support from the people they left behind, especially after the mid-12th-century drought ended and maize became more abundant. But this is no more than conjecture, and more data are needed to convincingly support or refute the idea of an in-migration of a "McElmo" people to the Canyon if we are to under understand who was supplying corn to the Canyon during the A.D. 1180s.

\section{Summary and conclusions}

Thirty cobs from Chaco Canyon great houses (Pueblo Bonito, Kin Klizhin, and Chetro Ketl) and Gallo Cliff Dwelling were found to have a pooled calibrated age of A.D. $1180 \pm 10$. Nine of the 30 cobs were subjected to an intense cleaning procedure that unfortunately removed most of the metals attached to weak ion-exchange sites within the cob's organic matrix. This experiment effectively proved that the cleaning procedure that had been developed to treat burned cobs by Benson et al. (2009) is not applicable to unburned cobs. Metal loss from the cleaned cobs effectively negated the possibility of obtaining ${ }^{87} \mathrm{Sr} /{ }^{86} \mathrm{Sr}$ ratios that were representative of the bioavailable $\mathrm{Sr}$ associated with the field(s) in which the corn was grown. An additional nine of the 30 cobs were judged to be contaminated with mineral matter to the point that their ${ }^{87} \mathrm{Sr} /{ }^{86} \mathrm{Sr}$ ratios were not considered reliable (Benson et al., 2009).

The ${ }^{87} \mathrm{Sr} /{ }^{86} \mathrm{Sr}$ ratios of the remaining 12 cobs (Table 1 ) were compared with the ${ }^{87} \mathrm{Sr} /{ }^{86} \mathrm{Sr}$ ratios of synthetic soil waters (Fig. 5) from 14 regions within the southeastern Colorado Plateau (Fig. 2). For the purposes of this study, soil samples from 10 locations in each of three field areas (Pescado, Nutria, and Bear Canyon) within the Zuni region also were collected (Supplementary Table 1).

The ${ }^{87} \mathrm{Sr} /{ }^{86} \mathrm{Sr}$ data indicate that the Chaco Canyon archaeological cobs that date to the late A.D. 1100s did not come from the Chaco Halo, instead the data suggest five potential source areas for the cobs, including: the Nutria field area in the Zuni region, the Mesa Verde-McElmo Dome area, the Totah area, the Defiance Plateau, and Lobo Mesa. The latter two areas were eliminated from consideration in that they appear to have been unpopulated during the time period of interest. Therefore, it appears that the cobs were imported from the Zuni region, the Mesa Verde-McElmo Dome area, or the Totah area during a time when the climate was relatively wet and when a surplus of corn was being produced in regions outside Chaco Canyon. It is suggested that the Totah area is the most likely source of the corn based on the Totah's proximity to Chaco Canyon and also with regard to the Chacoan origin of the people that had migrated to the Totah area in the early A.D. 1100s. 
The data presented in this paper do not rule out contribution of maize to Chaco from other satellite communities nor does it demonstrate that maize was not being grown in Chaco Canyon either before or after the mid-12th-century drought. Unfortunately, available archaeological cobs from Chaco Canyon contexts are few in number and are not evenly distributed over time. As a result, we probably will never have sufficient cobs to determine a complete set of possible source areas from the inception of the earliest great houses (Pueblo Bonito, Una Vida, and Penasco Blanco) in the A.D. 850s until the complete abandonment of the Canyon in the A.D. 1290s.

The fact that available cob ${ }^{87} \mathrm{Sr} /{ }^{86} \mathrm{Sr}$ data indicate that the corn was grown outside the Canyon suggests that the residual Canyon population was receiving food from external sources. Unfortunately, these data are not sufficient in themselves to reveal the relationship of the group(s) that supplied corn to Chaco after the mid-12th-century drought to those still residing in Chaco.

\section{Acknowledgments}

The author wishes to thank Roman Pawluk, Director of the Zuni Conservation Program, for facilitating access to Zuni field sites and to Daniel Bowannie and Patterson Peynetsa who guided the author to field sites and assisted in the sampling effort. We also thank Dabney Ford and Wendy Bustard, Chaco Culture National History Park, Chaco Canyon, New Mexico who allowed access to archaeological cobs from Gallo Cliff Dwelling and Chetro Ketl. The author is also grateful for the assistance of Jeffrey Homburg who provided a copy of his Ph. D. dissertation to the author as well as topographic maps of the Zuni region, showing the locations of previously studied field systems. My special thanks to Terry Plowman who processed many of the cob samples and to David Roth and Ron Antweiler who, respectively, analyzed the synthetic soil waters and processed the raw analytical data. Mike Berry provided the treering cutting data for the Wide Weed Ruin site. Discussions with Catherine Cameron, Tom Windes, and William Lipe were especially helpful. Howard Taylor and Michael Berry provided helpful reviews of an earlier version of this manuscript. Field work and isotopic analysis for this project were supported by U.S. Department of the Interior, Bureau of Reclamation Acquisition No. 08-AA-40-2789.

\section{Appendix. Supplementary material}

Supplementary data associated with this article can be found, in the online version, at doi:10.1016/j.jas.2009.10.027.

\section{References}

Adams, K.R., Meegan, C.M., Ortman, S.G., Howell, R.E., Werth, L.C., Muenchrath, D.A., O'Neill, M.K., Gardner, C.A.C., 2006. MAIS (Maize of American Indigenous Societies) Southwest: ear descriptions and traits that distinguish 27 morphologically distinct groups of 123 historic USDA maize (Zea mays L. spp. Mays) accessions and data relevant to archaeological subsistence models. http:// spectre.nmsu.edu (Projects And Results, Collaborative MAIS Experiment).

Benson, L.V., Berry, M.S., 2009. Climate change and cultural response in the American Southwest. Kiva 75, 89-119.

Benson, L., Cordell, L., Vincent, K., Taylor, H., Stein, J., Farmer, G.L., Futa, K., 2003. Ancient maize from Chacoan great houses: where was it grown? Proceedings of the National Academy of Sciences 100, 13111-13115.

Benson, L.V., Petersen, K., Stein, J., 2007. Anasazi (pre-Columbian Native-American) migrations during the middle-12th and late-13th centuries - were they drought induced? Climatic Change 83, 187-213.

Benson, L.V., Taylor, H.E., Peterson, K.A., Shattuck, B.D., Ramotnik, C.A., Stein, J.R., 2008. Development and evaluation of geochemical methods for the sourcing of archaeological maize. Journal of Archaeological Science 35, 912-921.

Benson, L.V., Stein, J.R., Taylor, H.E., 2009. Possible sources of archaeological maize found in Chaco Canyon and Aztec Ruin, New Mexico. Journal of Archaeological Science 36, 387-407.

Benson, L.V., Taylor, H.E., Plowman, T.I., Roth, D.A., Antweiler, R.C., 2010. The cleaning of burned and contaminated archaeological maize prior to ${ }^{87} \mathrm{Sr} /{ }^{86} \mathrm{Sr}$ analysis. Journal of Archaeological Science 37, 84-91.
Boss, C.B., Fredeen, K.J., 1999. Concepts, Instrumentation, and Techniques in Inductively Coupled Plasma Optical Emission Spectrometry. Perkin Elmer Corporation, Norwalk, Connecticut.

Brown, G.M., Windes, T.C., McKenna, P.J., 2008. Animas anamnesis: Aztec ruins or Anasazi capital? In: Reed, P.F. (Ed.), Chaco's Northern Prodigies. The University of Utah Press, Salt Lake City, pp. 231-250.

Cameron, C.M., Duff, A.I., 2008. History and process in village formation: context and contrasts from the northern Southwest. American Antiquity 73, 29-57.

Cordell, L.S., Toll, H.W., Toll, M.S., Windes, T.C., 2008. Archaeological corn from Pueblo Bonito, Chaco Canyon, New Mexico: dates, contexts, sources. American Antiquity 73, 491-511.

Doyel, D.E., Breternitz, C.D., Marshall, M.P., 1984. Chacoan community structure: Bis sa'ani Pueblo and the Chaco Halo. In: Judge, W.J., Schelberg, J.D. (Eds.), Recent Research on Chaco Prehistory. Reports of the Chaco Center No. 8. National Park Service, U.S. Department of the Interior, Albuquerque, pp. 37-54.

English, N.B., Betancourt, J.L., Dean, J.S., Quade, J., 2001. Strontium isotopes reveal distant sources of architectural timber in Chaco Canyon, New Mexico. Proceedings of the National Academy of Sciences 98, 11891-11896.

Fowler, A.P., Stein, J.R., 1992. The Anasazi great house in space, time, and paradigm. In: Doyel, D.E. (Ed.), Anasazi Regional Organization and the Chaco System. Maxwell Museum of Anthropology Anthropological Papers No. 5, pp. 101-122.

Garbarino, J.R., Taylor, H.E., 1993. Inductively coupled plasma-mass spectrometric method for the determination of dissolved trace elements in natural water. U.S. Geological Survey Open-File Report 94-358.

Homburg, J.A., Sandor, J.A., Norton, J.B., 2005. Anthropogenic influences on Zuni agricultural soils. Geoarchaeology 20, 661-693.

Judge, W.J., 1989. Chaco Canyon-San Juan Basin. In: Cordell, L.S., Gumerman, G.J. (Eds.), Dynamics of Southwest Prehistory. Smithsonian Institution Press, Washington D.C., pp. 209-261.

Kantner, J.W., Kintigh, K.W., 2006. The Chaco world. In: Lekson, S.H. (Ed.), The Archeology of Chaco Canyon: An Eleventh Century Pueblo Regional Center. School of American Research Press, Santa Fe, pp. 153-188.

Kintigh, K.W., Glowacki, D.M., Huntley, D.L., 2004. Long-term settlement history and the emergence of towns in the Zuni area. American Antiquity 69, 432-456.

Lekson, S.H., 1986. Great Pueblo Architecture of Chaco Canyon. University of New Mexico Press, Albuquerque.

Lekson, S.H., 1991. Settlement pattern and the Chaco region. In: Crown, P.L., Judge, W.J. (Eds.), Chaco and Hohokam: Prehistoric Regional Systems in the American Southwest. School of American Research Press, Santa Fe, pp. 31-55.

Lekson, S.H., 2006. Chaco matters: an introduction. In: Lekson, S.H. (Ed.), The Archeology of Chaco Canyon: An Eleventh Century Pueblo Regional Center. School of American Research Press, Santa Fe, pp. 3-44.

Lekson, S.H., 2009. A History of the Ancient Southwest. School for Advanced Research Press, Santa Fe.

Reed, P.F., 2006. Salmon Pueblo: Chacoan outlier and 13th-century middle San Juan community center. In: Reed, P.F. (Ed.), Thirty-Five Years of Archaeological Research at Salmon Ruins. Introduction, Architecture, Chronology, and Conclusions, vol. 1. Center for Desert Archaeology, Tucson, pp. 367-376. and Salmon Ruins Museum, Bloomfield, New Mexico.

Reed, P.F., 2008. Setting the stage: a reconsideration of Salmon, Aztec, and the middle San Juan region in Chacoan and post-Chacoan Puebloan history. In: Reed, P.F. (Ed.), Chaco's Northern Prodigies. The University of Utah Press, Salt Lake City, pp. 3-28.

Stuiver, M., Reimer, P.J., Reimer, R.W., 2005. CALIB Information and Download Page. http://depts.washington.edu/qil/.

Taylor, H.E., 2001. Inductively Coupled Plasma-Mass Spectrometry: Practices and Techniques. Academic Press, San Diego.

Toll, H.W., 1991. Material distributions and exchange in the Chaco System. In: Crown, P., Judge, W.J. (Eds.), Chaco and Hohokam. School of American Research, Santa Fe, pp. 77-107.

Varien, M.D., 2002. Persistent communities and mobile households: population movement in the central Mesa Verde region, A.D. 950 to 1290. In: Varien, M.D. Wilshusen, R.H. (Eds.), Seeking the Center Place, Archaeology and Ancient Communities in the Mesa Verde Region. The University of Utah Press, Salt Lake City, pp. 163-184.

Varien, M.D., Ortman, S.G., Kohler, T.A., Glowacki, D.M., Johnson, C.D., 2007 Historical ecology in the Mesa Verde region: results from the Village Ecodynamics Project. American Antiquity 72, 273-299.

Vivian, R.G., Hilpert, B., 2002. The Chaco Handbook. The University of Utah Press, Salt Lake City.

Vivian, R.G., Matthews, T.W., 1965. Kin Kletso, a Pueblo III Community in Chaco Canyon, New Mexico. In: Southwestern Monuments Association Technical Series, vol. 8. Globe, Arizona.

Wilshusen, R.H., Ortman, S.G., 1999. Rethinking the Pueblo I period in the San Juan drainage: aggregation, migration, and cultural diversity. Kiva 64, 369-399.

Wilshusen, R.H., Van Dyke, R.M., 2006. Chaco's beginnings. In: Lekson, S.H. (Ed.), The Archeology of Chaco Canyon: An Eleventh Century Pueblo Regional Center. School of American Research Press, Santa Fe, pp. 211-259.

Windes, T.C., 2003. This old house: construction and abandonment at Pueblo Bonito. In: Neitzel, J.E. (Ed.), Pueblo Bonito: Center of the Chacoan World. Smithsonian Books, Washington D.C.

Windes, T.C., Anderson, R.M., Johnson, B.K., Ford, C.A., 2000. Sunrise, sunset: sedentism and mobility in the Chaco East Community. In: Kantner, J., Mahoney, N. (Eds.), Great House Communities across the Chacoan Landscape. The University of Arizona Press, Tucson, pp. 39-59. 